\title{
Pengaruh Current Ratio dan Total Assets Turnover Terhadap Price to Book Value Dengan Dimediasi Oleh Return On Equity pada Perusahaan Sub Sektor Farmasi Yang Terdaftar Di Bursa Efek Indonesia
}

\author{
Hendrick Sasimtan Putra
}

Program Studi Magister Manajemen, Universitas Muhammadiyah Sumatera Utara Medan, Indonesia Jl. Denai No. 217, Tegal Sari Mandala II, Medan Denai, Kota Medan, Sumatera Utara 20371 Email : hendrick.tan1995@gmail.com

\begin{abstract}
Abstrak. Penelitian ini bertujuan untuk mengetahui dan menganalisis Pengaruh Current Ratio dan Total Assets Turnover Terhadap Price to Book Value dengan Dimediasi oleh Return On Equity pada Perusahaan Sub Sektor Farmasi yang Terdaftar di Bursa Efek Indonesia. Penelitian ini menggunakan metode pendekatan pendekatan asosiatif. Populasi yang digunakan dalam penelitian ini adalah 10 perusahaan Sub Sektor Farmasi yang terdaftar di Bursa Efek Indonesia. Sedangkan sampel yang diambil sebanyak 7 perusahaan dengan menggunakan purposive sampling. Untuk memperoleh data yang diperlukan dalam penelitian ini, penulis menggunakan teknik dokumentasi dari data-data yang dipublikasikan oleh perusahaan di situs resmi BEI www.idx.co.id. Serta laporan tahunan yang dimiliki oleh perusahaan. Tenik analisis data dalam penelitian ini yaitu menggunakan analisis jalur (Path Analysis), uji asumsi klasik, regresi linear berganda, uji t, uji F dan koefisien determinasi. Hasil penelitian ini menunjukkan secara parsial bahwa Current Ratio berpengaruh positif dan tidak signifikan terhadap Price to Book Value. Total Assets Turnover berpengaruh negatif dan tidak signifikan terhadap Price to Book Value. Current Ratio berpengaruh negatif dan tidak signifikan terhadap Return On Equity. Total Assets Turnover berpengaruh negatif signifikan terhadap Return On Equity. Secara simultan Current Ratio dan Total Assets Turnover berpengaruh tidak signifikan terhadap Price to Book Value yang dimediasi oleh Return On Equity. Return On Equity tidak dapat memediasi pengaruh Current Ratio terhadap Price to Book Value dan Return On Equity tidak dapat memediasi pengaruh Total Assets Turnover terhadap Price to Book Value pada Perusahaan Sub Sektor Farmasi yang Terdaftar di Bursa Efek Indonesia.
\end{abstract}

Kata Kunci : Current Ratio, Total Assets Turnover, Return On Equity, Price to Book Value

\begin{abstract}
This study aims to determine and analyze the Effect of Current Ratio and Total Assets Turnover against Price to Book Value Mediated by Return On Equity in Pharmaceutical Sector Sub Company Listed in Indonesia Stock Exchange. This study uses associative approach approach. The population used in this study is 10 Sub Sector Pharmaceutical Company listed on the Indonesia Stock Exchange. While the samples take 7 companies using purposive sampling. To obtain the necessary data in this study, the author used a documentation technique of the data published by the company on the official website of the Stock Exchange www.idx.co.id. As well as the annual report which is owned by the company. Analysis data technique in this research is Using Path Analysis, Classical Assumption test, multiple linear regression, $t$ test, $F$ test and coefficient of determination.The results of this study indicate that partially, the Current Ratio has no significant positive effect on the Price to Book Value. Total Assets Turnover has no significant negative effect on the Price to Book Value. Current Ratio hasno significant negative effect on Return On Equity. Total Assets Turnover has a significant negative effect on Return On Equity. Simultaneously, Current Ratio and Total Assets Turnover has no significant effect on Price to Book Value that mediated by Return On Equity. Return On Equity can not mediate the effect of Current Ratio of Price to Book Value and Return On Equity can not mediate the effect of Total Assets Turnover to Price to Book Value in the Sub Sector Pharmaceutical Company Listed in Indonesia Stock Exchange.
\end{abstract}

Keywords : Current Ratio, Total Assets Turnover, Return on Equity, Price to Book Value 


\section{PENDAHULUAN}

Meningkatnya situasi persaingan yang dihadapi oleh perusahaan saat ini menuntut peran seorang manajer yang mampu mengelola keuangan perusahaan dengan baik serta mampu memakmurkan para pemegang saham (Jufrizen \& Sagala, 2019). Tujuan utama perusahaan go public adalah untuk meningkatkan kemakmuran para pemegang saham yang dapat dilihat melalui meningkatnya nilai perusahaan yang tercermin dari harga sahamnya. Untuk itu perusahaanakan selalu berupaya untuk meningkatkan nilai perusahaannya (Jufrizen, 2012).

Perusahaan sub sektor Farmasi atau obat-obatan adalah perusahaan bisnis komersialisasi yang berfokus dalam meneliti, mengembangkan dan mendistribusikan obat-obatan maupun peralatan kesehatan. Perusahaan ini juga merupakan tipe perusahaan industrial yang diminati oleh investor asing maupun domestik, karena peluang industri yang masih menjanjikan di Indonesia. Untuk menanamkan modalnya para investor memperhatikan nilai perusahaannya.

Nilai perusahaan merupakan nilai yang bergantung pada peluangnya untuk tumbuh, dimana peluang ini bergantung pada kemampuannya untuk menarik modal (Jufrizen \& Fatin, 2020). Nilai perusahaan merupakan rasio yang menghubungkan harga saham perusahaan dengan laba dan nilai buku per saham. Rasio ini memberi indikasi kepada manajemen mengenai pendapat investor tentang prestasi perusahaan di masa lalu dan prospeknya di masa yang akan datang. Perusahaan yang dipandang baik oleh investor adalah perusahaan dengan laba dan arus kas yang aman, mengalami pertumbuhan, dijual dengan rasio nilai buku yang lebih tinggi dibandingkan perusahaan dengan tingkat pengembalian yang rendah. Menurut (Brigham \& Houston, 2011), nilai perusahaan dapat dipengaruhi oleh faktor internal yaitu likuiditas, manajemen aset, manajemen utang, dan profitabilitas. Sedangkan faktor eksternal yang mempengaruhinya yaitu tingkat inflasi dan tingkat bunga. Salah satu alat ukur nilai perusahaan adalah Price to Book Value (PBV) yang digunakan untuk menggambarkan perbandingan antara harga saham dan nilai buku per saham yang ada di laporan posisi keuangan. Current Ratio merupakan salah satu rasio yang terdapat dalam rasio likuiditas. Menurut (Kasmir, 2016), rasio likuiditas (liquidity ratio) merupakan rasio yang menggambarkan kemampuan perusahaan dalam memenuhi kewajiban jangka pendeknya bila jatuh tempo.

Total Assets Turnover merupakan salah satu rasio yang terdapat pada rasio aktivitas. Menurut (Kasmir, 2016), rasio aktivitas merupakan rasio yang digunakan untuk mengukur efektivitas perusahaan dalam menggunakan aktiva yang dimilikinya. Atau dapat pula dikatakan rasio ini digunakan untuk mengukur tingkat efisien pemanfaatan sumber daya perusahaan.

Return On Equity merupakan salah satu rasio yang terdapat dalam rasio profitabilitas. Menurut (Sudana, 2015) rasio profitabilitas adalah rasio yang mengukur kemampuan perusahaan untuk menghasilkan laba menggunakan sumber-sumber yang dimiliki perusahaan, seperti aset, ekuitas, atau penjualan perusahaan.

Tabel 1. Rata-rata Current Ratio, Total Assets Turnover, Return On Equity, Price to Book Value Perusahaan Sub Sektor Farmasi yang Terdaftar di Bursa Efek Indonesia Periode 2013-2018

\begin{tabular}{lccccccc|}
\hline \multicolumn{1}{c}{ Keterangan } & 2013 & 2014 & 2015 & 2016 & 2017 & 2018 & Rata-rata Per Tahun \\
\hline Current Ratio & 3,611 & 4,349 & 3,801 & 3,734 & 3,665 & 2,831 & 3,665 \\
Total Assets Turnover & 1,283 & 1,201 & 1,250 & 1,202 & 1,149 & 0,985 & 1,178 \\
Return On Equity & 0,176 & 0,158 & 0,151 & 0,151 & 0,149 & 0,442 & 0,204 \\
Price to Book Value & 2,949 & 3,300 & 2,236 & 2,907 & 2,732 & 2,471 & 2,766 \\
\hline Sumber: www.idx.com (2019) & & & & & & \\
\hline
\end{tabular}

Penurunan Price to Book Value diduga oleh harga saham cenderung naik yang disebabkan karena adanya penurunan harga saham yang diikuti dengan lebih besarnya 
peningkatan nilai buku ekuitas. Menurut (Brigham \& Houston, 2011), faktor-faktor internal yang mempengaruhi nilai perusahaan yaitu likuiditas, manajemen aset, manajemen utang, dan profitabilitas. Faktor yang digunakan dalam penelitian ini hanya sebatas pada likuiditas, aktivitas dan ukuran perusahaan. Oleh karena itu, penting untuk perusahaan mengetahui dan mempertimbangkan faktor-faktor yang mempengaruhi nilai perusahaan.

Hal ini sesuai dengan penelitian yang dilakukan oleh (Sugiarto, 2011) yang melakukan penelitian tentang analisa pengaruh BETA, size perusahaan, DER dan PBV Ratio terhadap return saham menyatakan perusahaan dengan Price to Book Value di atas satu, menunjukkan bahwa perusahaan dapat beroperasi dengan baik yang menunjukkan nilai pasar saham lebih tinggi dibanding dengan nilai bukunya.

Current Ratio adalah perbandingan antara aktiva lancar dengan liabilitas lancar. Berdasarkan data di atas terlihat bahwa Current Ratio mengalami penurunan bila dilihat dari rata-rata per perusahaannya. Hal ini diduga karena adanya penurunan rata-rata jumlah aktiva lancar yang diikuti dengan lebih kecilnya penurunan hutang lancar. Semakin tinggi rasio berarti terjamin utang-utang perusahaan kepada kreditur, dan sebaliknya pula apabila semakin rendah rasio berarti mencerminkan ketidakmampuan perusahaan dalam membayar utangnya kepada kreditur. Hal ini sesuai dengan penelitian yang dilakukan oleh (Deitiana, 2013) yang melakukan penelitian mengenai pengaruh current ratio, return on equity dan total assets turnover terhadap devidend payout ratio dan implikasi pada harga saham menyatakan perusahaan dengan tingkat likuiditas yang tinggi menunjukkan posisi keuangan yang kuat dan mampu memenuhi kewajiban keuangan kepada pihak luar secara tepat waktu, mampu menjaga kondisi modal kerja yang cukup, mampu membayar bunga dan kewajiban dividen yang harus dibayarkan, dan menjaga posisi kredit utang yang aman.

Total Assets Turnover adalah perbandingan penjualan dengan total aktiva. Disini terlihat bahwa Total Assets Turnover mengalami peningkatan bila dilihat dari rata-rata pertahunnya. Hal ini dapat diduga bahwa penjualan lebih besar dibanding dengan total aktiva perusahaan. Dan dalam hal ini menunjukkan bahwa dengan semakin tingginya nilai perputaran aset mencerminkan semakin tinggi pula nilai penjualan terhadap nilai total aset. Hal ini sesuai dengan penelitian yang dilakukan oleh (Deitiana, 2013) mengenai pengaruh current ratio, return on equity dan total assets turnover terhadap devidend payout ratio dan implikasi pada harga saham yang menyatakan perusahaan dengan tingkat assets turnover yang tinggi menunjukkan bahwa perusahaan semakin efektif dalam menggunakan sumber dayanya yang berupa penggunaan aset dan semakin cepat pengembalian dana dalam bentuk kas.

Berdasarkan data di atas terlihat bahwa Return On Equity mengalami penurunan. Hal ini dapat diduga karena adanya penurunan laba bersih yang diikuti dengan lebih kecilnya peningkatan total ekuitas. Oleh karena itu, penting untuk perusahaan mengetahui dan mempertimbangkan faktor-faktor yang mempengaruhi Return On Equity. Menurut (Brigham \& Houston, 2011), faktor-faktor yang mempengaruhi profitabilitas antara lain likuiditas, manajemen utang (leverage), margin laba bersih, perputaran total aktiva, pertumbuhan perusahaan dan ukuran perusahaan. Hal ini sesuai dengan penelitian yang dilakukan oleh (Ayem \& Nugroho, 2016) mengenai pengaruh profitabilitas, strukutr modal, kebijakan deviden, dan keputusan investasi terhadap nilai perusahaan yang menyatakan perusahaan dengan tingkat pengembalian atau profitabilitas yang tinggi cenderung menggunakan dana sendiri atau laba ditahan yang diperoleh dari operasionalnya untuk melanjutkan operasional perusahaan tersebut.

Dari fenomena diatas, dapat dilihat bahwa kondisi nilai perusahaan pada perusahaan Sub Sektor Farmasi yang terdaftar di Bursa Efek Indonesia dalam kondisi kurang baik. Dapat dilihat dari terjadinya peningkatan terhadap hutang lancar, menurunnya perputaran aktiva, dan profit. 


\section{LANDASAN TEORI}

\section{Price to Book Value}

Rasio Price to Book Value (PBV) adalah suatu nilai yang digunakan untuk membandingkan apakah sebuah saham relatif lebih mahal atau lebih murah bila dibandingkan dengan harga saham lainnya. Perusahaan yang tingkat pengembalian atas ekuitasnya tinggi biasanya menjual sahamnya dengan penggandaan nilai buku yang lebih tinggi dari pada perusahaan lain yang tingkat pengembaliannya rendah.

Menurut (Murhadi, 2013) Price Book Value (PBV) adalah rasio yang menggambarkan perbandingan antara harga pasar saham dan nilai buku ekuitas sebagaimana yang ada di laporan posisi keuangan. Rasio Price to Book Value (PBV) ini membandingkan antara market value dengan Book Value suatu saham. Dengan rasio PBV ini, investor dapat mengetahui langsung sudah berapa kali market value suatu saham dihargai dari Book Value-nya.

Sedangkan menurut (Rahardjo, 2009) menyatakan bahwa Rasio harga pasar atas nilai buku (Price to Book Value) merupakan pembagian harga pasar atas nilai buku (Price to Book Value) merupakan pembagian harga pasar per lembar saham dengan nilai buku per lembar saham. Rasio ini membandingkan nilai pasar investasi pada perusahaan dengan biayanya. Nilai yang lebih kecil dari satu berarti bahwa perusahaan gagal menciptakan nilai bagi pemegang sahamnya. Menurut (Brigham \& Houston, 2011), nilai perusahaan didefinisikan sebagai tujuan utama dari keputusan manajerial dengan mempertimbangkan resiko dan waktu yang terkait dengan perkiraan laba per saham untuk memaksimalkan harga saham biasa perusahaan. Menurut (Prihadi, 2019), penjualan (sales) merupakan faktor penentu pertama besarnya nilai perusahaan. Besarnya penjualan menunjukan sampai seberapa jauh produk perusahaan diterima oleh pelanggan. Semakin banyak penjualan, berarti semakin banyak produk yang diterima oleh pelanggan.

Pada dasarnya profitabilitas memiliki kemampuan mengasilkan laba perusahaan, tetapi bila kita lihat kembali profitabilitas mempunyai peranan yang sangat penting dalam meningkatkan nilai perusahaan karena profitabilitas mampu mengukur laba yang didapatkan oleh perusahaan. Sedangkan menurut (Pradana \& Sanjaya, 2017), menyatakan bahwa ada beberapa faktor yang mempengaruhi nilai perusahaan diantaranya: keputusan pendanaan, kebijakan dividen, keputusan investasi, pertumbuhan perusahaan, dan ukuran perusahaan.

Nilai paerusahaan pada penelitian diproksikan dengan Price to Book Value (PBV). Price to book value yang tinggi akan membuat pasar percaya atas prospek perusahaan ke depan. Prospek perusahaan yang menjanjikan kebaikan di masa mendatang, akan membuat para investor yakin terhadap dana yang ditanamnya ke perusahaan. Hal itu juga menjadi keinginan para pemilik perusahaan, sebab nilai perusahaan yang tinggi mengindikasikan kemakmuran pemegang saham juga tinggi.

Menurut (Brigham \& Houston, 2011) untuk mengukur nilai perusahaan dapat menggunakan rasio PBV, rasio ini menjelaskan bahwa harga pasar suatu saham dalam nilai bukunya memberikan indikasi pandangan investor atas perusahaan. Perusahaan dipandang baik oleh investor artinya perusahaan dengan laba dan arus kas yang aman serta terus mengalami pertumbuhan. Rasio ini dapat dihitung dengan menggunakan rumus:

$$
\text { Price to Book Value }=\frac{\text { Harga Pasar Per Saham }}{\text { Nilai Buku Per Lembar Saham }}
$$

Rasio ini menunjukkan bahwa pendekatan alternatif juga bisa dipakai dalam rasio ini untuk menilai suatu saham, karena secara teoritis nilai pasar suatu saham haruslah mencerminkan nilai bukunya. Agar bisa melihat atau mencerminkan nilai dari suatu perusahaan yang dapat dilihat dari harga sahamnya. 
Menurut (Hani, 2014), Price to Book Value diukur dengan rasio pasar terhadap nilai buku (market to book value ratio). Rasio ini dapat dihitung dengan menggunakan rumus sebagai berikut:

$$
\text { Price to Book Value }=\frac{\text { Harga Saham }}{\text { Nilai Buku Per Lembar Saham }}
$$

Nilai perusahaan yang baik ketika nilai Price to Book Value diatas satu yaitu nilai pasar lebih besar daripada nilai buku perusahaan. Semakin tinggi nilai Price to Book Value menunjukkan nilai perusahaan semakin baik. Sebaliknya, apabila Price to Book Value dibawah nilai satu mencerminkan nilai perusahaan lebih rendah dibandingkan dengan nilai buku.

Menurut Fahmi (2014:85), Price to Book Value dapat dihitung dengan rumus:

Price to Book Value $=\frac{\text { Market price per share }}{\text { Book Value per Share }}$

Nilai buku per lembar saham menunjukkan jumlah rupiah yang akan dibayarkan kepada setiap lembar saham apabila perusahaan pada saat itu dibubarkan dengan anggapan bahwa semua aktiva dapat dijual dengan harga yang sama dengan nilai bukunya.

\section{Current Ratio}

Current Ratio merupakan salah satu rasio yang terdapat di rasio likuiditas. Menurut (Sartono, 2010), likuiditas merupakan kemampuan perusahaan untuk membayar kemampuan finansial jangka pendek tepat pada waktunya. Current Ratio merupakan salah satu rasio yang terdapat dalam rasio likuiditas.

Menurut (Kasmir, 2009), Rasio lancar atau Current Ratio merupakan rasio untuk mengukur kemampuan perusahaan dalam membayar kewajiban jangka pendek yang segera jatuh tempo pada saat ditagih secara keseluruhan dari aktiva lancarnya.

Menurut (Munawir, 2014), current Ratio yaitu rasio antara aktiva lancar dengan hutang lancar. Pihak yang paling berkepentingan terhadap rasio lancar adalah kreditor jangka pendek seperti pemasok. Rasio lancar memiliki hubungan antara aktiva lancar dengan kewajiban lancar. Semakin besar aktiva lancar maka semakin tinggi rasio lancar.

Selanjutnya menurut Riyanto (2009), Current Ratio merupakan ukuran yang berharga untuk mengukur kesanggupan suatu perusahaan untuk memenuhi current obligation-nya.

Menurut (Hanafi \& Halim, 2016), rasio lancar dihitung dengan membagi aktiva lancar dengan hutang lancar. Rasio ini menunjukkan besarnya kas yang dipunyai perusahaan ditambah aset-aset yang bisa berubah menjadi kas dalam waktu satu tahun, relatif terhadap besarnya hutang-hutang yang jatuh tempo dalam jangka waktu dekat (tidak lebih dari 1 tahun), pada tanggal tertentu seperti tercantum dalam neraca.

Menurut (Jumingan, 2018) faktor yang mempengaruhi Current Ratio, diantaranya: Perlu dianalisis lebih lanjut misalnya apakah surat-surat berharga yang dimiliki dapat segera diuangkan, bagaimana tingkat pengumpulan piutang, bagaimana tingkat perputaran persediaan. Penting juga dalam membandingkan antara aktiva lancar dengan utang jangka pendek, menyebut pos masing-masing beserta jumlah rupiahnya dan membandingkan dengan rasio industri.

Menurut (Riyanto, 2013), perubahan tingkat Current Ratio disebabkan 3 faktor, yaitu:

1. Dengan hutang lancar (Current Liabilities) tertentu, diusahakan untuk menambah aktiva lancar atau Current Assets.

2. Dengan aktiva lancar tertentu, diusahakan untuk mengurangi jumlah hutang lancar.

3. Dengan mengurangi jumlah hutang lancar bersama-sama dengan mengurangi aktiva lancar. 
Sedangkan menurut (Kasmir, 2016), faktor-faktor yang mempengaruhi likuditas yaitu: Ketidakmampuan perusahaan membayar kewajibannya terutama utang jangka pendek (yang sudah jatuh tempo) disebabkan oleh berbagai faktor. Pertama, bisa dikarenakan memang perusahaan sedang tidak memiliki dana sama sekali. Atau kedua, bisa mungkin saja perusahaan memiliki dana (tidak cukup) secara tunai sehingga harus menunggu dalam waktu tertentu, untuk mencairkan aktiva lainnya seperti menagih piutang, menjual surat-surat berharga, atau menjual persediaan atau aktiva lainnya.

Menurut (Kasmir, 2016), rasio lancar dapat dirumuskan sebagai berikut:

$$
\text { Current Ratio }=\frac{\text { Aktiva Lancar }(\text { Current Asset })}{\text { Hutang Lancar }(\text { Current Liabilities })}
$$

\section{Total Assets Turnover}

Total Assets Turnover merupakan salahsatu rasio yang terdapat dalam rasio aktivitas. Menurut (Kasmir, 2016), Rasio perputaran aktiva (assets turnover) adalah rasio yang digunakan untuk mengukur penggunaan semua aktiva perusahaan dan jumlah penjualan yang diperoleh dari tiap rupiah aktiva.

Menurut (Munawir, 2018), Total Assets Turnover merupakan kemampuan dana yang tertanam dalam keseluruhan aktiva berputar dalam suatu periode tertentu atau kemampuan modal yang diinvestasikan untuk menghasilkan revenue.

Selanjutnya menurut (Sartono, 2010), perputaran total aktiva, menunjukkan bagaimana efektivitas perusahaan menggunakan keseluruhan aktiva untuk menciptakan penjualan dan mendapatkan laba. Semakin tinggi total assets turnover, maka akan semakin tinggi tingkat efisiensi perusahaan dalam penggunaan aktivanya sehingga membuat penilaian aktiva baru.

Menurut (Hani, 2015) menyatakan bahwa, Total Assets Turnover yaitu rasio untuk mengukur efisiensi penggunaan aktiva secara keseluruhan selama satu periode. Merupakan ukuran tentang sampai seberapa jauh aktiva telah dipergunakan di dalam kegiatan perusahaan atau menunjukkan berapa kali aktiva yang digunakan dalam kegiatan operasi berputar dalam satu periode tertentu. Tingginya total assets turnover menunjukkan aktivitas penggunaan harta perusahaan. Perputaran aktiva yang lambat menunjukkan bahwa aktiva yang dimiliki terlalu besar dibandingkan dengan kemampuan untuk melakukan usaha. Menurut (Harmono, 2015), faktor yang mempengaruhi rasio aktivitas diantaranya: 1) Inventory Turnover (perputaran persediaan), 2) Account Receivable (perputaran piutang), 3) Total Assets Turnover (perputaran aktiva), dan 4) Cash Turnover (perputaran kas).

Rumus untuk menghitung total assets turnover menurut (Kasmir, 2016), yaitu:

$$
\text { Total Assets Turnover }=\frac{\text { Penjualan }(\text { Sales })}{\text { Total Aktiva }(\text { Total Assets })}
$$

\section{Return On Equity}

Return On Equity merupakan salah satu rasio dalam Profitabilitas. Laba seringkali menjadi salah satu ukuran kerja perusahaan. Dimana ketika perusahaan memiliki laba yang tinggi berarti kinerjanya baik dan sebaliknya. Laba perusahaan selain merupakan indikator kemampuan perusahaan memenuhi kewajiban bagi para penyandang dananya juga merupakan elemen dalam penciptaan nilai perusahaan yang menunjukkan prospek perusahaan di masa yang akan datang.

Menurut (Kasmir, 2016), hasil pengembalian Ekuitas atau Return On Equity merupakan rasio untuk mengukur laba bersih sesudah pajak dengan modal sendiri. Rasio ini menunjukkan 
efisiensi penggunaan modal sendiri. Semakin tinggi resiko ini, makin baik. Artinya, posisi pemilik perusahaan makin kuat, demikian pula sebaliknya.

Menurut (Hery, 2016) menyatakan bahwa: Return On Equity (ROE) merupakan rasio yang menunjukkan seberapa besar kontribusi ekuitas dalam menciptakan laba bersih. Dengan kata lain, rasio ini digunakan untuk mengukur seberapa besar jumlah laba bersih yang akan dihasilkan dari setiap rupiah dana yang tertanam dalam total ekuitas. Rasio ini dihitung dengan membagi laba bersih terhadap ekuitas. Semakin tinggi hasil pengembalian atas ekuitas berarti semakin tinggi pula jumlah laba bersih yang dihasilkan dari setiap dana yang tertanam dalam ekuitas.

Sedangkan menurut Sudana (2011), rasio profitabilitas adalah rasio yang mengukur kemampuan perusahaan untuk menghasilkan laba menggunakan sumber-sumber yang dimiliki perusahaan, seperti aset, ekuitas, atau penjualan perusahaan.

Menurut (Riyanto, 2013), profitabilitas suatu perusahaan dipengaruhi oleh:

1. Tingkat pengembalian atas investasi, untuk melihat kompensasi keuangan kepada peneyedia pendanaan ekuitas dan hutang.

2. Kinerja operasi untuk mengevaluasi margin laba dari aktivitas operasi.

3. Pemanfaatan aset, untuk menilai efektivitas dan intensitas aktivitas dalam menghasilkan penjualan.

Sesuai dengan tujuan yang hendak dicapai, terdapat beberapa cara untuk mengukur tingkat profitabilitas suatu perusahaan. Masing-masing jenis rasio profitabilitas, digunakan untuk menilai serta mengukur posisi keuangan perusahaan dalam satu periode tertentu atau untk beberapa periode. Menurut Kasmir (2010:115), perhitungan Return On Equity adalah sebagai berikut:

$\mathrm{ROE}=\frac{\text { Earning After Interest and Tax }}{\text { Equity }}$

\section{METODE PENELITIAN}

Pendekatan penelitian yang digunakan dalam penelitian ini adalah pendekatan asosiatif. Jenis data yang digunakan bersifat kuantitatif, yaitu berbentuk angka (Data Sekunder) dengan menggunakan skala rasio dengan berdasarkan formula yang dijadikan sebagai dasar pengukuran serta menggunakan alat analisis statistik berupa Path Analysis. Populasi dalam penelitian ini adalah seluruh pusahaan sub sektor Farmasi yang terdaftar di Bursa Efek Indonesia sebanyak 10 perusahaan. Prosedur peilihan sampel dilakukan dengan teknik purposive sampling, maka sampel dalam penelitian ini sebanyak 7 perusahaan. Data sekunder dari penelitian ini diperoleh dari publikasi laporan keuangan perusahaan yang terdaftar di Bursa Efek Indonesia. Pengolahan data menggunakan perangkat lunak SPSS versi 21. Analisis statisitk inferensial dalam penelitian ini meliputi: uji asumsi klasik, regresi analisis jalur, uji hipotesis dan uji koefisien determinasi.

\section{HASIL DAN PEMBAHASAN PENELITIAN Hasil Penelitian}

Uji normalitas digunakan untuk menguji apakah model regresi antara variabel bebas dan variabel terikat mempunyai distribusi normal, hal ini dapat dilihat dengan pengujian grafik P-Plot, nilai VIF dan scatterplot. 


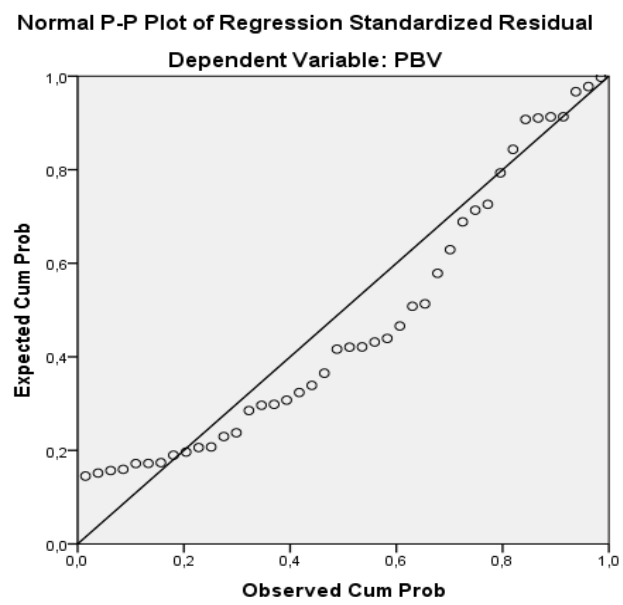

Gambar 1. Hasil P-Plot Normalitas Data

Berdasarkan gambar diatas terlihat bahwa hasil dari uji normalitas data menunjukkan penyebaran titik-titik data cenderung mendekati garis diagonal atau grafik histogramnya menunjukkan pola distribusi normal, maka model regresi memenuhi asumsi normalitas. Hal ini menyimpulkan bahwa metode regresi berdisitribusi normal dan layak untuk dianalisis.

Tabel 2. Uji Multikolinearitas

\begin{tabular}{|c|c|c|c|}
\hline \multirow{2}{*}{\multicolumn{2}{|c|}{ Model }} & \multicolumn{2}{|c|}{ Collinearity Statistics } \\
\hline & & Tolerance & VIF \\
\hline \multirow{4}{*}{1} & (Const & & \\
\hline & $\mathrm{CR}$ & ,765 & 1,308 \\
\hline & TATO & 678 & 1,474 \\
\hline & ROE & ,804 & 1,244 \\
\hline
\end{tabular}

a. Dependent Variable: PBV

Dari data pada tabel diatas dapat diketahui bahwa tidak terjadi gejala multikolinearitas antara variabel independen yang diindikasikan dari nilai tolerance setiap variabel independen lebih besar dari 0,1 dan nilai VIF lebih kecil dari 10 (Juliandi, Irfan, \& Manurung, 2015). Maka dapat disimpulkan bahwa analisis lebih lanjut dapat dilakukan dengan menggunakan model regresi berganda.

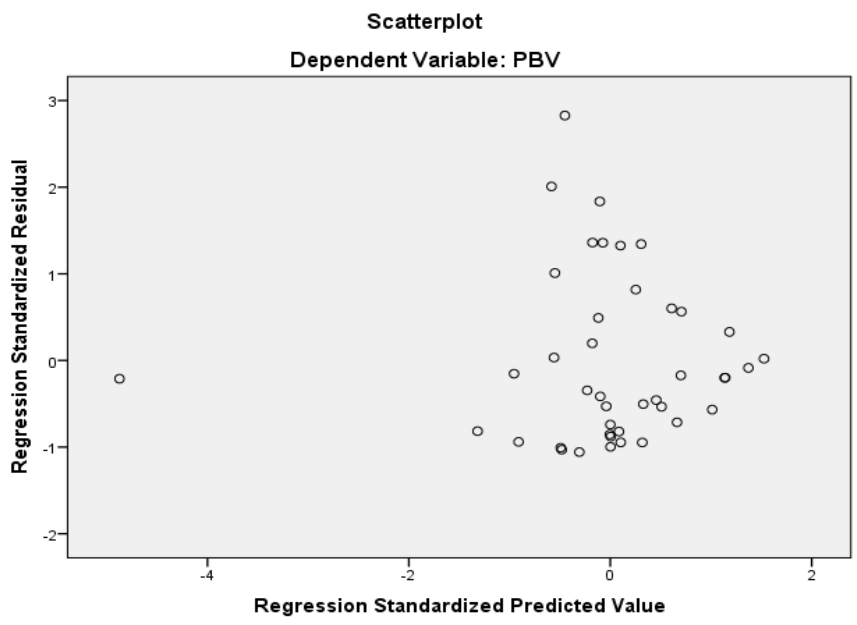

Gambar 2. Scatterplot Uji Heteroskedastisitas

Bentuk gambar diatas, dapat ita lihat bahwa titik-titik menyebar secara acak, serta tidak membentuk pola atau garis tertentu yang teratur baik di bagian atas angka nol atau dibagian 
bawah angka nol dari sumbu vertikal atau pada sumbu Y. Hal ini menunjukkan bahwa tidak terjadi heteroskedastisitas pada model regresi.

Persamaan regresi I bervariabel mediator/intervening (mediation model with regression) adalah sebagai berikut:

Tabel 3. Hasil Regresi I

\begin{tabular}{|c|c|c|c|c|c|c|}
\hline \multirow{2}{*}{\multicolumn{2}{|c|}{ Model }} & \multirow{2}{*}{\multicolumn{2}{|c|}{$\begin{array}{l}\text { Unstandardized } \\
\text { Coefficients }\end{array}$}} & \multirow{2}{*}{$\begin{array}{l}\text { Standardized } \\
\text { Coefficients } \\
\text { Beta }\end{array}$} & \multirow[t]{2}{*}{$\mathrm{t}$} & Sig. \\
\hline & & & & & & \\
\hline \multirow{3}{*}{1} & (Constant) & 1029 & 272 & & 3784 & 001 \\
\hline & CR &,- 047 & ,025 &,- 297 & $-1,889$ &, 066 \\
\hline & TATO &,- 554 &, 185 &,- 471 & $-2,998$ &, 005 \\
\hline
\end{tabular}

Berdasarkan tabel 3 diatas dapat kita ketahui bahwa Koefisien $x_{1}$ adalah $\rho_{z x_{1}}=-0,297$ dan Koefisien $x_{2}$ adalah $\rho_{z x_{2}}=-0,471$.

Persamaan regresi II bervariabel mediator/intervening (mediation variable with regression) adalah sebagai berikut:

Tabel 4. Hasil Regresi II

\begin{tabular}{|c|c|c|c|c|c|c|}
\hline \multirow[t]{2}{*}{ Model } & & \multicolumn{2}{|c|}{$\begin{array}{l}\text { Unstandardized } \\
\text { Coefficients }\end{array}$} & $\begin{array}{l}\text { Standardized } \\
\text { Coefficients }\end{array}$ & $\mathrm{t}$ & Sig. \\
\hline & & $\mathrm{B}$ & Std. Error & Beta & & \\
\hline \multirow{4}{*}{1} & (Constant) & 3,769 & 2,283 & & 1,651 & 107 \\
\hline & $\overline{\mathrm{CR}}$ & ,045 & 185 & 044 & 243 & 809 \\
\hline & TATO &,- 774 & 1,474 &,- 101 &,- 525 & 603 \\
\hline & $\overline{\mathrm{ROE}}$ & $-1,251$ & 1,150 &,- 193 & $-1,088$ & ,284 \\
\hline
\end{tabular}

a. Dependent Variable: PBV

Berdasarkan tabel 4 diatas dapat kita ketahui bahwa Koefisien $x_{1}$ adalah $\rho_{y x_{1}}=0,044$, Koefisien $x_{2}$ adalah $\rho_{y x_{2}}=-0,101$, Koefisien $z$ adalah $\rho_{y z}=-0,193$.

Adapun bentuk pengaruh langsung atau tidak langsung dari variabel $\mathrm{X} 1$ terhadap $\mathrm{Y}$ yang dimediasi oleh $\mathrm{Z}$ adalah sebagai berikut.

Tabel 5. Rumusan Pengaruh Langsung dan Pengaruh Tidak Langsung

\begin{tabular}{|c|c|c|c|c|c|}
\hline \multirow{3}{*}{$\begin{array}{l}\text { Pengaruh } \\
\text { Variabel }\end{array}$} & \multicolumn{4}{|c|}{ Pengaruh } & \multirow[b]{3}{*}{ Total } \\
\hline & \multirow[b]{2}{*}{ Langsung } & \multicolumn{3}{|c|}{ Tidak Langsung } & \\
\hline & & $\begin{array}{c}\text { melalui } \\
\mathrm{X}_{1}\end{array}$ & $\begin{array}{c}\text { melalui } \\
\mathrm{X}_{2}\end{array}$ & $\begin{array}{c}\text { melalui } \\
\mathrm{Z}\end{array}$ & \\
\hline $\begin{array}{l}\mathrm{X}_{1} \text { terhadap } \\
\mathrm{Y}\end{array}$ & 0,002 & & 0,002 & 0,001 & $\begin{array}{l}0,002+0,002+0,001= \\
0,005\end{array}$ \\
\hline $\begin{array}{l}\mathrm{X}_{2} \text { terhadap } \\
\mathrm{Y}\end{array}$ & 0,010 & 0,002 & & $-0,007$ & $\begin{array}{l}0,010+0,002-0,007= \\
0,005\end{array}$ \\
\hline $\mathrm{Z}$ terhadap $\mathrm{Y}$ & 0,037 & 0,001 & $-0,007$ & & $\begin{array}{l}0,037+0,001-0,007= \\
0,031\end{array}$ \\
\hline Pengaruh secar & a simultan & & & & $0,005+0,005+0,031=$ \\
\hline Pengaruh varia & bel luar & & & & $1-0,041=0,959$ \\
\hline
\end{tabular}

Berdasarkan output regresi sub struktur II di atas pada tabel coefficient, diketahui bahwa nilai signifikansi dari ketiga variabel yaitu $\mathrm{X}_{1}=0,809, \mathrm{X}_{2}=0,603$ lebih besar dari 0,05 .Hasil ini memberikan kesimpulan bahwa regresi sub struktur II yakni variabel $\mathrm{X}_{1}$ dan $\mathrm{X}_{2}$ berpengaruh signifikan terhadap Y. Sementara nilai signifikan dari $Z=0,284$ lebih besar dari 0,05. Dan besar nya nilai signifikan $Z$ dari pada 0,05 memberikan kesimpulan bahwa $Z$ 
berpengaruh signifikan terhadap $\mathrm{Y}$. Besarnya nilai $\mathrm{R}^{2}$ atau Rsquare yang terdapat dalam tabel model summary adalah sebesar 0,041 atau $4,1 \%$ sementara sisanya $95,9 \%$ yang merupakan kontribusi dari variabel-variabel lain yang tidak dimasukkan dalam penelitian ini.

Adapun model diagram jalur penelitian ini berdasarkan paradigma hubungan antar-variabel adalah sebagai berikut :

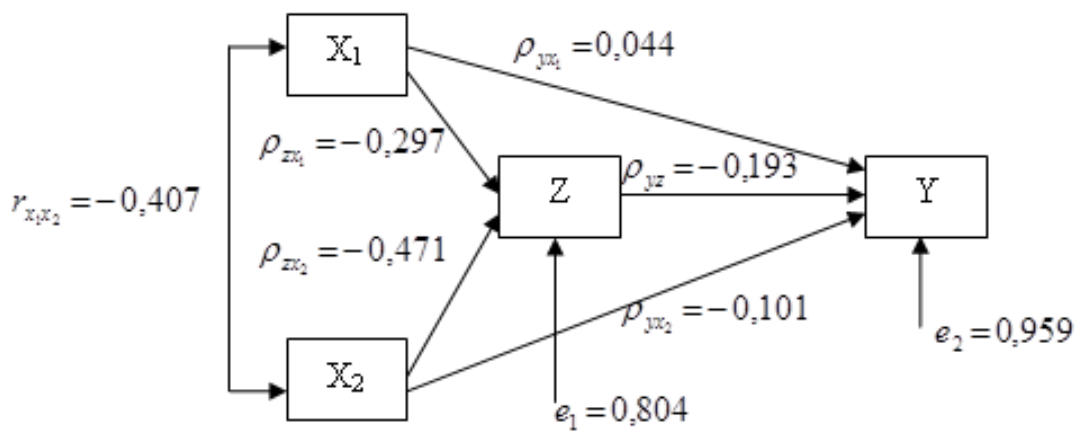

Gambar 3.

Hubungan Struktural Variabel Current Ratio, Total Assets Turnover, Return On Equity dan Price to Book Value

\section{Pembahasan}

\section{Pengaruh Current Ratio terhadap Price to Book Value}

Hasil penelitian yang diperoleh mengenai pengaruh Current Ratio terhadap Price to Book Value adalah hasil uji hipotesis secara parsial yang menunjukkan bahwa nilai $t_{\text {hitung }}$ Current Ratio sebesar $-2,998$ dan $\mathrm{t}_{\text {tabel }}$ dengan $\alpha=5 \%$ diketahui sebesar 2,023. Dengan demikian $-\mathrm{t}_{\text {tabel }}$ lebih kecil dari $t_{\text {hitung }}$ dan $t_{\text {hitung }}$ lebih kecil dari $t_{\text {tabel }}(-2,023<0,243<2,023)$. Nilai signifikansi sebesar 0,809 (lebih besar dari 0,05) artinya $\mathrm{H}_{0}$ diterima dan $\mathrm{H}_{\mathrm{a}}$ ditolak. Hal ini menunjukkan bahwa secara parsial Current Ratio berpengaruh tidak signifikan terhadap Price to Book Value pada Perusahaan Sub Sektor Farmasi yang terdaftar di Bursa Efek Indonesia.

Dari hasil penelitian di atas menunjukkan penurunan Current Ratio dari tahun ke tahun mempengaruhi nilai Price to Book Value. Walaupun tidak langsung, Nilai Current Ratio yang tinggi mengidentifikasi nilai aktiva lancar lebih besar daripada nilai hutang lancar yang memberikan gambaran bahwa piutang dari perusahaan meningkat sehingga meningkatkan jumlah persediaan di perusahaan, dengan meningkatnya jumlah persediaaan pada perusahaan menunjukkan bahwa penjualan perusahaan menurun sehingga membuat profitabilitas menurun dan akibatnya berefek pada menurunnya Price to Book Value, berdasarkan pada teori signaling dengan menurunnya Price to Book Value memberikan sinyal yang tidak baik kepada pemegang saham sehingga dapat menurunkan nilai perusahaan.

Hasil penelitian ini sesuai dengan penelitian yang dilakukan oleh (Erawati, 2015) yang menyatakan bahwa likuiditas yang diukur dengan Current Ratio tidak berpengaruh signifikan terhadap PBV (nilai perusahaan). Tetapi, hasil penelitian ini tidak sejalan dengan penelitian yang dilakukan oleh (Rompas, 2013) dan (Anzlina \& Rustam, 2013) yang menyatakan Current Ratio berpengaruh signifikan terhadap nilai perusahaan.

Berdasarkan hasil penelitian di atas dapat disimpulkan bahwa terdapat kesesuaian penelitian terdahulu dengan hasil penelitian yaitu Current Ratio berpengaruh tidak signifikan terhadap Price to Book Value. 


\section{Pengaruh Total Assets Turnover terhadap Price to Book Value}

Hasil penelitian yang diperoleh mengenai pengaruh Total Assets Turnover terhadap Price to Book Value adalah hasil uji hipotesis secara parsial yang menunjukkan bahwa nilai $\mathrm{t}_{\text {hitung }}$ Total Assets Turnover sebesar -0,525 dan $\mathrm{t}_{\text {tabel }}$ dengan $\alpha=5 \%$ diketahui sebesar 2,023. Dengan demikian $-t_{\text {tabel }}$ lebih kecil dari $t_{\text {hitung }}$ dan $t_{\text {hitung }}$ lebih kecil dari $t_{\text {tabel }}(-2,023<-0,525<2,023)$. Nilai signifikansi sebesar 0,603 (lebih besar dari 0,05) artinya $\mathrm{H}_{0}$ diterima dan $\mathrm{H}_{\mathrm{a}}$ ditolak. Hal ini menunjukkan bahwa secara parsial Total Assets Turnover berpengaruh tidak signifikan terhadap Price to Book Value pada Perusahaan Sub Sektor Farmasi yang terdaftar di Bursa Efek Indonesia.

Dari hasil penelitian di atas menunjukkan peningkatan Total Assets Turnover dari tahun ke tahun mempengaruhi nilai Price to Book Value. Walaupun tidak langsung, tingginya nilai Total Assets Turnover menunjukkan semakin efektif penggunaan aktiva perusahaan dalam rangka memperoleh laba dari penjualan perusahaan. Semakin tinggi TATO menunjukkan bahwa pendayagunaan aset perusahaan dalam rangka perusahaan memperoleh penjualan akan semakin tinggi. Namun, perusahaan kurang mampu mengefektifkan penggunaan hutang sebagai penambahan modal, sehingga laba yang dihasilkan mengalami penurunan. Penurunan laba tersebut juga berpengaruh dari beban hutang yang bertambah yang diikuti dengan penurunan Return On Equity dan Price to Book Value.

Hasil penelitian ini sesuai dengan penelitian yang dilakukan oleh Misran (2017) yang menyatakan bahwa Total Assets Turnover berpengaruh terhadap Price to Book Value. Dan menurut penelitian (Siswoyo, 2012) yang Total Assets Turnover berpengaruh terhadap Price to Book Value.

Berdasarkan hasil penelitian di atas dapat disimpulkan bahwa terdapat kesesuaian penelitian terdahulu dengan hasil penelitian yaitu Total Assets Turnover berpengaruh tidak signifikan terhadap Price to Book Value.

\section{Pengaruh Current Ratio terhadap Return On Equity}

Hasil penelitian yang diperoleh mengenai pengaruh Current Ratio terhadap Return On Equity adalah hasil uji hipotesis secara parsial yang menunjukkan bahwa nilai $t_{\text {hitung }}$ Current Ratio sebesar $-1,889$ dan $t_{\text {tabel }}$ dengan $\alpha=5 \%$ diketahui sebesar 2,021. Dengan demikian $-t_{\text {tabel }}$ lebih kecil dari $t_{\text {hitung }}$ dan $t_{\text {hitung }}$ lebih kecil dari $t_{\text {tabel }}(-2,021<-1,889<2,021)$. Nilai signifikansi sebesar 0,066 (lebih besar dari 0,05) artinya $\mathrm{H}_{0}$ diterima dan $\mathrm{H}_{\mathrm{a}}$ ditolak. Hal ini menunjukkan bahwa secara parsial Current Ratio berpengaruh tidak signifikan terhadap Return On Equity pada Perusahaan Sub Sektor Farmasi yang terdaftar di Bursa Efek Indonesia.

Dari hasil penelitian di atas menunjukkan penurunan Current Ratio dari tahun ke tahun mempengaruhi nilai Return On Equity. Menurunnya Current Ratio menunjukkan bahwa dana kas digunakan untuk menutupi hutang jangka panjang sehingga beban bunga berkurang yang dibayar dari kas mengakibatkan laba mengalami peningkatan. Laba yang meningkat tersebut akan mempengaruhi Return On Equity yang meningkat.

Hasil penelitian ini tidak sesuai dengan penelitian yang dilakukan oleh (Munadhiroh \& Nurchayati, 2015) yang berkesimpulan bahwa terdapat pengaruh signifikan antara variabel Current Ratio terhadap Return On Equity. Namun pada penelitian yang dilakukan oleh Anwar Puteh (2013) berkesimpulan bahwa Current Ratio memiliki pengaruh yang tidak signifikan terhadap Return On Equity.

Berdasarkan hasil penelitian di atas dapat disimpulkan bahwa terdapat kesesuaian penelitian terdahulu dengan hasil penelitian yaitu Current Ratio berpengaruh tidak signifikan terhadap Return On Equity. 


\section{Pengaruh Total Assets Turnover terhadap Return On Equity}

Hasil penelitian yang diperoleh mengenai pengaruh Total Assets Turnover terhadap Return On Equity adalah hasil uji hipotesis secara parsial yang menunjukkan bahwa nilai $t_{\text {hitung }}$ Total Assets Turnover sebesar -2,998 dan $\mathrm{t}_{\text {tabel }}$ dengan $\alpha=5 \%$ diketahui sebesar 2,021. Dengan demikian $-t_{\text {tabel }}$ lebih kecil dari $t_{\text {hitung }}$ dan $t_{\text {hitung }}$ lebih kecil dari $t_{\text {tabel }}(-2,998<-2,021<2,021)$. Nilai signifikansi sebesar 0,005 (lebih kecil dari 0,05) artinya $\mathrm{H}_{0}$ ditolak dan $\mathrm{H}_{\mathrm{a}}$ diterima. Hal ini menunjukkan bahwa secara parsial Total Assets Turnover berpengaruh negatif signifikan terhadap Return On Equity pada Perusahaan Sub Sektor Farmasi yang terdaftar di Bursa Efek Indonesia.

Dari hasil penelitian di atas menunjukkan peningkatan Total Assets Turnover dari tahun ke tahun mempengaruhi nilai Return On Equity. Namun pengaruh Total Assets Turnover terhadap Return On Equity tersebut memiliki pengaruh negatif yang mana jikalau Total Assets Turnover mengalami penurunan, maka Return On Equity perusahaan akan meningkat. Hal tersebut bisa saja terjadi karena kondisi penjualan laba yang berasal dari penjualan lebih besar dibanding dengan tambahan jumlah beban bunga. Peningkatan laba tersebut dijadikan sebagai penambah modal dari laba ditahan sehingga sebagian besar perusahaan berusaha untuk menambah aktiva tetap melalui penambahan modal baik yang berasal dari utang jangka panjang.

Hasil penelitian ini sesuai dengan salah satu teori. Menurut (Harahap, 2016), Total Assets Turnover merupakan rasio yang menunjukkan perputaran total aktiva diukur dari volume penjualan dengan kata lain seberapa jauh kemampuan semua aktiva menciptakan penjualan. Penelitian ini sejalan dengan penelitian yang dilakukan oleh (Puteh, 2013), berkesimpulan bahwa Total Assets Turnover berpengaruh signifikan terhadap Return On Equity.

Berdasarkan hasil penelitian di atas dapat disimpulkan bahwa terdapat kesesuaian teori, penelitian terdahulu dengan hasil penelitian yaitu Total Assets Turnover berpengaruh signifikan terhadap Return On Equity.

\section{Pengaruh Current Ratio terhadap Price to Book Value dengan dimediasi oleh Return On Equity}

Dari hasil pengujian hipotesis melalui analisis jalur menunjukkan bahwa Current Ratio berpengaruh tidak langsung terhadap Price to Book Value. Hal ini dapat dilihat dari besarnya koefisien pengaruh langsung daripada pengaruh tidak langsung $(0,002>0,001)$. Hal ini mengindikasikan bahwa tinggi rendahnya Current Ratio tidak berpengaruh terhadap Price to Book Value. Current Ratio yang tinggi tersebut memang baik dari sudut pandang kreditur, tetapi dari sudut padang pemegang saham kurang mengutungkan karena aktiva lancar tidak didayagunakan dengan efektif. Sebaliknya Current Ratio yang rendah relatif lebih riskan, tetapi menunjukkan bahwa manajemen telah mengoperasikan aktiva lancar secara efektif.

Berdasarkan hasil pengujian analisis jalur menunjukkan bahwa Return On Equity tidak dapat memediasi pengaruh Current Ratio terhadap Price to Book Value.

\section{Pengaruh Total Assets Turnover terhadap Price to Book Value dengan dimediasi oleh Return On Equity}

Dari hasil pengujian hipotesis melalui analisis jalur menunjukkan bahwa Total Assets Turnover berpengaruh tidak langsung terhadap Price to Book Value. Hal ini dapat dilihat dari besarnya koefisien pengaruh langsung daripada pengaruh tidak langsung $(0,010>-0,007)$. Hal ini mengindikasikan bahwa tinggi rendahnya Total Assets Turnover tidak berpengaruh terhadap Price to Book Value. Semakin tinggi nilai Total Assets Turnover menunjukkan semakin efektifnya aset perusahaan dalam menghasilkan laba bagi perusahaan, hal ini merupakan sinyal 
positif bagi investor untuk berinvestasi dan memicu naiknya harga saham perusahaan, naiknya harga saham membuat nilai Price to Book Value juga naik. Berdasarkan hasil pengujian analisis jalur menunjukkan bahwa Return On Equity tidak dapat memediasi pengaruh Total Assets Turnover terhadap Price to Book Value.

\section{Pengaruh Current Ratio dan Total Assets Turnover terhadap Price to Book Value dengan dimediasi oleh Return On Equity}

Hasil penelitian yang diperoleh mengenai Current Ratio dan Total Assets Turnover terhadap Price to Book Value, dari uji ANOVA (Analysis of Variance), di dapat $\mathrm{F}_{\text {hitung }}$ sebesar 0,543 dengan tingkat signifikansi sebesar 0,656, sedangkan $\mathrm{F}_{\text {tabel }}$ diketahui sebesar 2,85. Berdasarkan hasil tersebut dapat diketahui bahwa $\mathrm{F}_{\text {hitung }}$ lebih kecil dari $\mathrm{F}_{\text {tabel }}(0,543<2,85)$, sehingga $\mathrm{H}_{0}$ diterima. Jadi dapat disimpulkan bahwa variabel Current Ratio, Total Assets Turnover dan Return On Equity secara simultan berpengaruh tidak signifikan terhadap Price to Book Value pada Perusahaan Sub Sektor Farmasi yang terdaftar di Bursa Efek Indonesia.

\section{SIMPULAN}

Berdasarkan hasil analisis yang telah dibahas maka dapat disimpulkan bahwa Current Ratio tidak berpengaruh signifikan terhadap Price to Book Value. Hal ini berarti bahwa dengan meningkatnya Current Ratio maka akan terjadi peningkatan tidak berdampak pada Price to Book Value, Total Assets Turnover berpengaruh negatif dan tidak signifikan terhadap Price to Book Value. Hal ini berarti bahwa dengan meningkatnya Total Assets Turnover maka akan terjadi penurunan pada Price to Book Value, Current Ratio berpengaruh negatif dan tidak signifikan terhadap Return On Equity. Hal ini berarti bahwa dengan meningkatnya Current Ratio maka akan terjadi penurunan pada Return On Equity, Total Assets Turnover berpengaruh negatif signifikan terhadap Return On Equity. Hal ini berarti bahwa dengan meningkatnya Total Assets Turnover maka akan terjadi penurunan pada Return On Equity, Dalam hasil uji hipotesis Analisis Jalur diketahui bahwa Current Ratio berpengaruh tidak signifikan negatif secara langsung terhadap Price to Book Value, namun pengaruh tersebut akan berkurang bila melalui Return On Equity, berarti Return On Equity bukan variabel mediasi karena dalam penelitian ini hasil pengaruh tidak langsungnya sangat kecil yaitu sebesar 0,1\%, Dalam hasil uji hipotesis Analisis Jalur diketahui bahwa Total Assets Turnover berpengaruh tidak signifikan negatif secara langsung terhadap Price to Book Value, namun pengaruh tersebut akan berkurang bila melalui Return On Equity, berarti Return On Equity bukan variabel mediasi karena dalam penelitian ini hasil pengaruh tidak langsungnya sangat kecil yaitu sebesar $-0,7 \%$, Dalam hasil uji hipotesis diketahui bahwa secara simultan Current Ratio dan Total Assets Turnover berpengaruh tidak signifikan terhadap Price to Book Value yang dimediasi oleh Return On Equity. Hal ini berarti bahwa pembiayaan hutang lancar melalui aset lancar harus diikuti dengan peningkatan perputaran aset agar perusahaan dapat menghasilkan laba yang maksimal. Peningkatan ini akan dipandang baik oleh investor.

\section{REFERENSI}

Anzlina, C. W., \& Rustam, R. (2013). Pengaruh Tingkat Likuiditas, Solvabilitas, Aktivitas, dan Profitabilitas Terhadap Nilai Perusahaan pada Perusahaan Real Estate dan Property di BEI Tahun 2006-2008. Jurnal Ekonomi, 16(2), 67-75.

Ayem, S., \& Nugroho, R. (2016). Pengaruh Profitabilitas, Struktur Modal, Kebijakan Deviden, Dan Keputusan Investasi Terhadap Nilai Perusahaan (Studi Kasus Perusahaan Manufaktur Yang Go Publik di Bursa Efek Indonesia) PERIODE 2010 - 2014. Jurnal Akuntansi, 4(1), $31-40$. 
Brigham, E. F., \& Houston, J. F. (2011). Dasar-dasar Manajemen Keuangan. Jakarta: PT. Salemba Empat.

Deitiana, T. (2013). Pengaruh Current Ratio, Return On Equity Dan Total Asset Turn Over Terhadap Devidend Payout Ratio Dan Implikasi Pada Harga Saham Perusahaan LQ 45. Jurnal Bisnis Dan Akuntansi, 15(1), 82-88. https://doi.org/10.34208/jba.v15i1.249

Erawati, D. (2015). Pengaruh Likuiditas, Manajemen Aset, Manajemen Liabilitas, Dan Profitabilitas Terhadap Harga Saham Pasar/Buku Pada Perusahaan Makanan Dan Minuman Yang Terdaftar Di Bei Periode Tahun 2008 - 2012. Jurnal Ilmu Manajemen Magistra, 1(1), 71-87.

Hanafi, M. M., \& Halim, A. (2016). Analisis Laporan Keuangan. Yogyakarta: UPP STIM YKPN Yogyakarta.

Hani, S. (2014). Teknik Anlisa Laporan Keuangan. Medan: Umsu Pres.

Hani, S. (2015). Teknik Analisa Laporan Keuangan. Medan: UMSU Press.

Harahap, S. S. (2016). Analisis Kritis Laporan Keuangan. Jakarta: Rajawali Pers.

Harmono. (2015). Manajemen Keuangan Berbasis Balances Scorecard Pendekatan Teori, Kasus, dan Riset Bisnis. Jakarta: Bumi Aksara.

Hery, H. (2016). Analisis Laporan Keuangan (1st ed.). Jakarta: PT Grasindo.

Jufrizen, J. (2012). Pengaruh Rasio Profitabilitas Terhadap Harga Saham pada Perusahaan yang Tercatat dalam LQ45 di Bursa Efek Indonesia. Jurnal Visioner \& Strategis, 1(2), 197211.

Jufrizen, J., \& Fatin, I. N. A. (2020). Pengaruh Debt To Equity Ratio, Return On Equity, Return On Assets Dan Ukuran Perusahaan Terhadap Nilai Perusahaan Pada Perusahaan Farmasi. Jurnal Humaniora: Jurnal Ilmu Sosial, Ekonomi Dan Hukum, 4(1), 183-195. https://doi.org/10.30601/humaniora.v4i1.677

Jufrizen, J., \& Sagala, D. A. P. H. (2019). Effect of Current Ratio, Debt To Equity Ratio, Net Profit Margin, and Total Asset Turnover on Earning Per Share. Internasional Conference on Global Education VII, 1(1), 1507-1521.

Juliandi, A., Irfan, I., \& Manurung, S. (2015). Metode Penelitian Bisnis : Konsep \& Aplikasi. In F. Zulkarnain (Ed.). Medan : UMSU PRESS.

Jumingan, J. (2018). Analisis Laporan Keuangan. Jakarta: Rajawali Pers.

Kasmir, K. (2009). Pengantar Manajemen Keuangan. Jakarta: Kencana.

Kasmir, K. (2016). Analisis Laporan Keuangan. Jakarta: Raja Grafindo Persada.

Munadhiroh, A., \& Nurchayati, N. (2015). Pengaruh Arus Kas Operasi Terhadap Profitabilitas (Studi Emperis pada Perusahaan Property Dan Real Estate Yang Terdaftar Di BEI). Serat Acitya - Jurnal Ilmiah UNTAG Semarang, 4(3), 59-69.

Munawir, S. (2014). Analisa Laporan Keuangan. Yogyakarta: Liberty Yogyakarta.

Munawir, S. (2018). Analisa Laporan Keuangan. Yogykarta: Liberty.

Murhadi, W. R. (2013). Analisis Laporan Keuangan, Proyeksi, dan Valuasi Saham. Jakarta: PT. Salemba Empat.

Pradana, S. W. L., \& Sanjaya, I. P. S. (2017). Dampak Profitabilitas, Aliran Kas Bebas, Dan Kesempatan Investasi Terhadap Pembayaran Dividen Perusahaan Perbankan. Jurnal Keuangan Dan Perbankan, 21(1), 113-124.

Prihadi, T. (2019). Analisis Laporan Keuangan Konsep \& Aplikasi. Jakarta: PT Gramedia Pustaka Utama.

Puteh, A. (2013). Pengaruh Current Ratio dan Total Assets Turnover Terhadap Return On Equity pada Perbankan yang Terdaftar di Bursa Efek Indonesia. In Semnas Fekon: Optimisme Ekonomi Indonesia 2013 (pp. 383-386). 
Rahardjo, B. (2009). Dasar-dasar Analisis Fundamental Saham Laporan Keuangan Perusahaan. Yogyakarta: Gadjah Mada University press.

Riyanto, B. (2013). Dasar-Dasar Pembelanjaan Perusahaan. Yogyakarta: BPFE.

Rompas, G. P. (2013). Likuiditas, Solvabilitas dan Rentabilitas Terhadap Nilai Perusahaan BUMN yang Terdaftar di Bursa Efek Indonesia. Jurnal EMBA: Jurnal Riset Ekonomi, Manajemen, Bisnis Dan Akuntansi, 1(3), 252-262. https://doi.org/10.35794/emba.v1i3.2014

Sartono, A. (2010). Manajemen Keuangan Teori dan Aplikasi (Cetakan 4). Yogyakarta : BPFE. Siswoyo, E. (2012). Analisis Rasio Aktivitas Terhadap Nilai Perusahaan yang Diukur dengan Metode Tobin's Q pada Perusahaan Kertas yang Go Public di Bursa Efek Indonesia. Jurnal Ilmu \& Riset Manajemen, 1(9).

Sudana, I. M. (2015). Manajemen Keuangan Perusahaan. Jakarta: Erlangga.

Sugiarto, A. (2011). Analisa Pengaruh Beta, Size Perusahaan, DER dan PBV Ratio Terhadap Return Saham. Jurnal Dinamika Akuntansi, 3(1), 8-14. https://doi.org/10.15294/jda.v3i1.1939 